\title{
Soybean performance as affected by desiccation time of Urochloa ruziziensis and grazing pressures ${ }^{1}$
}

\author{
Desempenho da cultura da soja influenciada pela época de dessecação de Urochloa \\ ruziziensis e pressões de pastejo
}

\author{
Julio Cezar Franchini ${ }^{2}$, Alvadi Antonio Balbinot Junior ${ }^{2 *}$, Henrique Debiasi ${ }^{2}$ e Osmar Conte ${ }^{2}$
}

\begin{abstract}
Integrated crop-livestock farming system have demonstrated various economic and environmental advantages. However, there is lack of information on the effects of different desiccation times of Urochloa ruziziensis and grazing pressures on the soybean performance. This study aimed to evaluate the performance of three soybean cultivars, sown after different desiccation times of $U$. ruziziensis grazed at three heights during the 2012/13 growing season, in southern Brazil. The $U$. ruziziensis were continuously grazed for 6 months by 6,4 and 2 animal units (AU) per hectare, leading to average pasture heights of 15;35; and $50 \mathrm{~cm}$, respectively. Each pasture height constituted a different experiment. The experiments were laid out using randomized complete block design (RCBD) with split-plot arrangement in four replications. The treatments consisted of four desiccation times $(35 ; 28 ; 20$; and 8 days before the soybean sowing), allocated in the main plots, and three soybean cultivars (Vmax RR; BMX Potência RR; and NA 5909 $\mathrm{RR}$ ), distributed in the subplots. Increased interval between U. ruziziensis desiccation and soybean sowing resulted in higher soybean plant density and height, but the effects on soybean grain yields were not significant. The highest soybean grain yield was obtained when the pasture height was maintained in $35 \mathrm{~cm}$, regardless of soybean cultivars. The performance of the three soybean cultivars was not influenced by the interaction between desiccation time and the pasture residue mass on the soil at soybean sowing, defined by the pasture height.
\end{abstract}

Key words: Glycine max L. Crop-livestock system. No-tillage system. Straw mass.

\begin{abstract}
RESUMO - O sistema integração lavoura-pecuária tem demonstrado várias vantagens econômicas e ambientais. No entanto, há carência de informações sobre os efeitos da pressão de pastejo de Urochloa ruziziensis e de épocas de dessecação sobre o desempenho da cultura da soja em sucessão. O objetivo desta pesquisa foi avaliar o desempenho de três cultivares de soja, semeadas após diferentes épocas de dessecação de pastagem de U. ruziziensis, manejada em três pressões de pastejo. Foram estudadas três alturas de manutenção da pastagem de $U$. ruziziensis, pastejadas de forma contínua por seis meses: $15 ; 35$ e $50 \mathrm{~cm}$, constituindo três experimentos. Em cada experimento foi utilizado o delineamento de blocos casualizados com parcelas subdivididas e com quatro repetições. Nas parcelas, foram alocadas quatro épocas de dessecação $(35 ; 28 ; 20$ e 8 dias antes da semeadura da soja) e, nas subparcelas, três cultivares de soja (Vmax RR, BMX Potência RR e NA 5909 RR). O aumento do intervalo entre a dessecação e a semeadura da soja propiciou maior densidade de plantas e maior crescimento em altura, sem afetar o rendimento de grãos. A altura da pastagem de $35 \mathrm{~cm}$ conferiu maior rendimento de grãos de soja, independentemente das cultivares. O desempenho das três cultivares de soja não foi influenciado pela interação entre quantidade de palha, definida pela altura da pastagem, e época de dessecação.
\end{abstract}

Palavras-chave: Glycine max L. Integração lavoura-pecuária. Sistema plantio direto. Quantidade de palha.

\footnotetext{
* Autor para correspondência

${ }^{1}$ Recebido para publicação em 20/01/2014; aprovado em 10/06/2014

Pesquisa financiada pela Empresa Brasileira de Pesquisa Agropecuária/EMBRAPA

${ }^{2}$ Embrapa Soja, Caixa Postal 231, Londrina-PR, Brasil, 86.001-970, julio.franchini@embrapa.br, alvadi.balbinot@embrapa.br, henrique. debiasi@embrapa.br, osmar.conte@embrapa.br
} 


\section{INTRODUCTION}

One of the major challenges faced by the agriculture is the sustainable use of environmental resources for food, fiber and bio-energy production, and at the same time, the conservation of the soil, air and water quality, as well the biodiversity (FOLEY et al., 2005). The land use intensification involving integrated crop-livestock farming systems (CLS) managed under no-tillage system (NT) has been a suitable option to enhance the profitability and sustainability of soybean production in tropical and subtropical regions (BALBINOT JR et al., 2009; BARTH NETO et al., 2014; NAIR et al., 2010).

Despite the increased CLS adoption, farmers still have various questions regarding the pasture management during transition between the livestock and crop phases. Urochloa ruziziensis has been one of the forage species mostly used by crop grain growers at the beginning of the activities with livestock. This species provides various advantages, such as easy desiccation with nonselective herbicides, high quality forage production, and lower clump formation than other grass species. In addition, $U$. ruziziensis has higher nutrient use efficiency and biomass accumulation compared to other Urochloa species (Pacheco et al., 2011). However, little information is available relative to the best management alternative of $U$. ruziziensis in terms of pasture height and its effects on subsequent soybean crop.

The mechanized soybean sowing after the grass desiccation has been reported to be hindered by the plant residue on the soil surface, depending on the straw quantity (BALBINOT JR et al., 2011; RICCE; ALVES; PRETE, 2011). Moreover, high amounts of straw on the soil surface can increase the tractor wheel slip during the sowing operation, as well promoting the straw accumulation among the planter rows (ARATANI et al., 2006). A small interval between the grass desiccation and the sowing may impair the initial soybean growth due to shading (SANTOS et al., 2007) and allelochemicals released (BALBINOT JR., 2004; SOUZA et al., 2006; TREZZI; VIDAL, 2004) by the straw. According Matallo et al. (2009), when the glyphosate (most used non-selective herbicide in Brazil) is applied just before the crop sowing, the herbicide can be exudate by the roots of the desiccated weeds, hindering the crop growth. In contrast, when the desiccation is carried out too early, the soil mulching can be significantly reduced (NASCENTE; CRUSCIOL, 2012), leading to weed emergence before the soybean sowing, and hence, the necessity for an additional application of non-selective herbicides (FLECK et al., 2004). Debiasi and Franchini (2012) found that the soybean yields decreased with the reduction in the interval between the desiccation of an ungrazed $U$. brizantha pasture and the crop sowing.
We hypothesized that the soybean performance may be affected by the heights of $U$. ruziziensis management used during the grazing as well as by the interval between the grass desiccation and the soybean sowing. Additionally, soybean response to these situations may be dependent on the cultivar. Therefore, this study aimed to evaluate the performance of three soybean cultivars grown at various desiccation times of a $U$. ruziziensis pasture managed at different heights, in a CLS under NT.

\section{MATERIAL AND METHODS}

The study was conducted in Londrina/PR (latitude $23^{\circ} 12^{\prime} \mathrm{S}$, longitude $51^{\circ} 11^{\prime} \mathrm{W}$ and altitude of $585 \mathrm{~m}$ ), in a clayey Rhodic Hapludox. Before the experiment establishment, the area was managed under NT for 15 years, with soybean cultivation in summer and wheat or oats in winter. Some soil chemical and physical properties of the experimental site before the experiment establishment are presented in Table 1. Despite the low rainfall observed on October 2012 (Figure 1), when the desiccation treatments were applied, the soil water content was sufficient to ensure the herbicide efficiency at all times. Furthermore, the rainfall amount and distribution were adequate to the soybean water requirements (Figure 1).

In March 2010, after the soybean harvest, the Urochloa ruziziensis was sown using a seeder with 13 rows spaced $17 \mathrm{~cm}$ each other, equipped with double disc furrow openers and fluted roller type seed meter adapted for fodder grass seeds. The sowing rate was $5 \mathrm{~kg} \mathrm{ha}^{-1}$ of pure live seeds, and there was no fertilizer application.

From October 2010 to May 2011, the area was subjected to uniform and continuous cattle grazing with an average of $2 \mathrm{AU}^{\mathrm{ha}} \mathrm{a}^{-1}$. In July 2011, 60 days after the removal of the cattle from de pasture, the field was fertilized with $45 \mathrm{~kg} \mathrm{ha}^{-1}$ of $\mathrm{N}$ (in the form of ammonium sulfate - $310 \mathrm{~g} \mathrm{~kg}^{-1} \mathrm{~N}$ ). From September to December 2011, another uniform and continuous cattle grazing was conducted, using the same animal stocking rate $\left(2 \mathrm{AU}^{-1} \mathrm{~h}^{-1}\right)$. On December 18, 2011 - 15 days after removal of the animals, when pasture reached an average height of $50 \mathrm{~cm}$, the experimental area was divided into three paddocks with 1.2 ha, totaling an area of 3.6 ha. Each paddock was used for different experiments, with the same treatments, but differing regarding to the grazing pressure. Therefore, the paddocks were subjected to different grazing pressures, identified by the average pasture height maintained during the grazing period: $15 \mathrm{~cm}( \pm 5 \mathrm{~cm})$, with an average stocking rate of $6 \mathrm{AU} \mathrm{ha}^{-1}$ (experiment $1) ; 35 \mathrm{~cm}( \pm 5 \mathrm{~cm})$, with an average stocking rate of $4 \mathrm{AU}$ $\mathrm{ha}^{-1}$ (experiment 2$)$; and $50 \mathrm{~cm}( \pm 5 \mathrm{~cm})$, with an average 
Table 1 - Some soil chemical and physical properties of the experimental site before the experiment establishment, on March 2010

\begin{tabular}{lccccccccc}
\hline $\begin{array}{c}\text { Soil layer } \\
(\mathrm{cm})\end{array}$ & $\begin{array}{c}\mathrm{pH} \\
\left(\mathrm{CaCl}_{2}\right)\end{array}$ & $\begin{array}{c}\text { Clay } \\
\left(\mathrm{g} \mathrm{kg}^{-1}\right)\end{array}$ & $\begin{array}{c}\mathrm{K} \\
---------------\mathrm{cmol}_{\mathrm{c}} \mathrm{dm}^{-3}--------------\end{array}$ & $\begin{array}{c}\mathrm{Ca} \\
\left(\mathrm{mg} \mathrm{dm}^{-3}\right)\end{array}$ & $\begin{array}{c}\mathrm{Mg} \\
\left(\mathrm{g} \mathrm{dm}^{-3}\right)\end{array}$ & $\begin{array}{c}\mathrm{CTC} \\
(\%)\end{array}$ \\
\hline $0-10$ & 5.32 & 735 & 0.90 & 3.73 & 1.53 & 9.27 & 17.1 & 22.0 & 65.8 \\
$10-20$ & 5.14 & 754 & 0.80 & 3.79 & 1.82 & 9.30 & 16.0 & 18.9 & 68.4 \\
$20-40$ & 5.09 & 757 & 0.41 & 3.63 & 1.48 & 8.17 & 8.5 & 16.0 & 66.6 \\
\hline
\end{tabular}

${ }^{1} \mathrm{P}$ : phosphorus obtained by Mehlich-1. ${ }^{2} \mathrm{OC}$ : organic carbon obtained by Walkley-Black method. ${ }^{3} \mathrm{~V}$ : base saturation

Figure 1 - Mean rainfall and air temperature during the desiccation period and the soybean growth cycle in 2011/12 growing season, at Londrina- PR

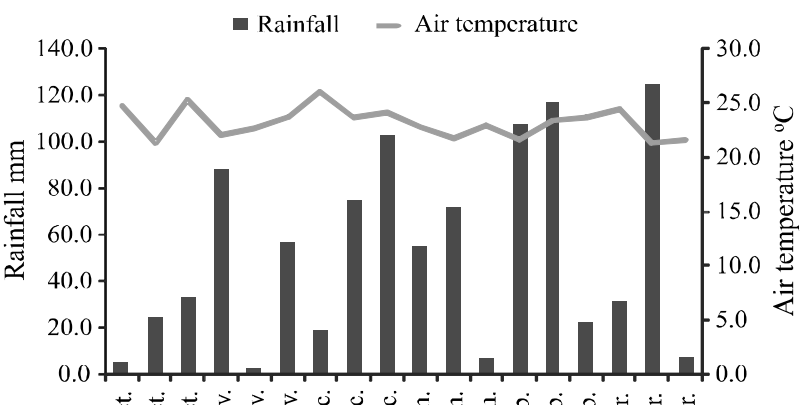

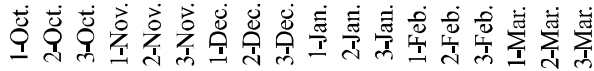

Ten-day periods

stocking rate of $2 \mathrm{AU} \mathrm{ha} \mathrm{h}^{-1}$ (experiment 3). The animals, male and female cattle, were kept in the paddocks until May 31, 2012. After this date, the area were maintained without grazing until October 2012, when an experiment in randomized complete block experimental design (RCBD) with split-plot arrangement and four replications were established in each paddock, totaling 3 experiments. The treatments consisted of four desiccation times (35; 28; 20; and 8 days before the soybean sowing), allocated in the main plots $\left(10 \mathrm{~m}\right.$ long $\mathrm{x} 15 \mathrm{~m}$ wide, $\left.150 \mathrm{~m}^{2}\right)$ and three soybean cultivars (Vmax RR; BMX Potência RR; and NA $5909 \mathrm{RR}$ ), distributed in the subplots (10 m long X $5 \mathrm{~m}$ wide, $50 \mathrm{~m}^{2}$ ).

The $U$. ruziziensis desiccation was performed by applying glyphosate at a dose of $2.52 \mathrm{~kg} \mathrm{ha}^{-1}$ e.a., using a tractor-mounted boom sprayer equipped with flat-fan nozzles, and an application volume of $200 \mathrm{~L} \mathrm{ha}^{-1}$. On November 06, 2012, the soybean was sown using a planter equipped with guillotine-type and double disk furrow openers for the fertilizer and seed deposition into the soil. The planter was adjusted to obtain 350,000 soybean plants per hectare in a $45-\mathrm{cm}$ row spacing. The soybean was fertilized with $50 \mathrm{~kg} \mathrm{ha}^{-1}$ of $\mathrm{P}_{2} \mathrm{O}_{5}$ and $50 \mathrm{~kg} \mathrm{ha}^{-1}$ of $\mathrm{K}_{2} \mathrm{O}$ (NPK 0-20-20, $250 \mathrm{~kg} \mathrm{ha}^{-1}$ ), applied $0.05 \mathrm{~m}$ below and alongside the seeds simultaneously with the sowing. The seeds were inoculated with Bradyrhizobium japonicum and B. elkanii, strains SEMIA 587 and SEMIA 5019. Other cultural practices, such as weed, pest and disease control, were performed according to the technical recommendation for soybean production in Paraná State, Brazil.

Straw samples were collected from an area of $2 \mathrm{~m}^{2}$ in each plot just before the soybean sowing. The samples were oven-dried at $65^{\circ} \mathrm{C}$ for 72 hours and the straw dry mass (SDM) on the soil was determined. The soybean plant density was evaluated at the V2 stage, by counting the plants contained in $3 \mathrm{~m}$ of central row in each subplot. Plant and first pod insertion heights were measured in 10 soybean plants randomly sampled from each subplot. The soybean grain yield was evaluated by mechanically harvesting $8 \mathrm{~m}$ of 3 central rows within each subplot. The seeds were cleaned, weighed, and the values were corrected to $0.13 \mathrm{~kg} \mathrm{~kg}^{-1}$ moisture content.

First, an analysis of variance (ANOVA) was performed separately for each experiment. As the residual variances among the three experiments were homogenous, a combined statistical analysis considering all the experiments together was performed. When the ANOVA resulted in a significant $\mathrm{P}$ value $(\mathrm{P}<0.05)$, the Tukey test was used for multiple comparison among means of grazing pressures and cultivars, whereas the means of desiccation times were analyzed by polynomial regression. The model with the best fit to the data and the studied phenomenon was selected. All the statistical analyses were performed at $5 \%$ probability level by the Sisvar software (FERREIRA, 2008).

\section{RESULTS AND DISCUSSION}

In the combined statistical analysis, the interactions between grazing pressures, desiccation times and soybean cultivars did not affect the parameters evaluated. The SDM on the soil at soybean sowing varied among grazing pressures (Table 2). The greatest SDM (more than $10 \mathrm{Mg} \mathrm{ha}^{-1}$ ) was observed 
Table 2 - Straw Dry Mass (SDM) on the soil surface at the soybean sowing, soybean growth and yield at different pasture (Urocholoa ruziziensis) heights (averaged over four desiccation times and three soybean varieties). Londrina, PR, Brazil, 2012/13 growing season

\begin{tabular}{|c|c|c|c|c|c|}
\hline $\begin{array}{c}\text { Pasture } \\
\text { height }(\mathrm{cm})\end{array}$ & $\begin{array}{c}\text { Straw dry mass } \\
\left(\mathrm{Mg} \mathrm{ha}^{-1}\right)\end{array}$ & $\begin{array}{c}\text { Plant density } \\
\left(1000 \text { plants ha }^{-1}\right)\end{array}$ & Plant height $(\mathrm{cm})$ & $\begin{array}{l}\text { First pod insertion } \\
\text { height }(\mathrm{cm})\end{array}$ & Grain yield $\left(\mathrm{kg} \mathrm{ha}^{-1}\right)$ \\
\hline 15 & $4.06 \mathrm{c}^{1}$ & $353 \mathrm{a}$ & $88.3 \mathrm{~b}$ & $19.3 \mathrm{~b}$ & $3931 \mathrm{~b}$ \\
\hline 35 & $6.79 \mathrm{~b}$ & $337 \mathrm{~b}$ & $95.6 \mathrm{a}$ & $21.0 \mathrm{a}$ & $4237 \mathrm{a}$ \\
\hline 50 & $10.75 \mathrm{a}$ & $322 \mathrm{c}$ & $87.9 \mathrm{~b}$ & $19.3 \mathrm{~b}$ & $3897 \mathrm{~b}$ \\
\hline $\mathrm{CV}(\%)$ & 17.6 & 7.7 & 11.7 & 13.5 & 12.1 \\
\hline
\end{tabular}

${ }^{1}$ Means followed by the same letters in a column do not differ by the Tukey test at $5 \%$ probability level

when the pasture was managed with the highest plant height $(50 \mathrm{~cm})$. In contrast, high grazing pressure and low grass height $(15 \mathrm{~cm})$ resulted in a smaller SDM on the soil at soybean sowing.

Soybean plant density was significantly affected by grazing pressure (Table 2). The lower the grazing pressure and higher the MS on the soil surface, the lower the soybean plant density (Table 2). The high SDM may have reduced the soybean plant density because of the physical barrier that may have hindered the externalization of the seedling stalks, and impaired seed deposition at appropriate depths for seedling emergence. Considering the high SDM on the soil under lower grazing pressures, the planter double discs may have incorporated straw into the furrow, leading to a reduced soil-seed contact, thus impairing the seed germination. Monquero et al. (2010) also reported reductions in soybean plant density due to high SDM on the soil surface, but the grain yields were not affected probably because of the great soybean phenotypic plasticity (HEIFFIG et al., 2006).

The highest soybean grain yield, plant height, and first pod insertion height occurred in the intermediate grazing pressure $(35 \mathrm{~cm})$ (Table 2). Under the greatest grazing pressure $(15 \mathrm{~cm})$, the soybean growth was likely impaired by the low SDM on soil surface, which leads to greater soil water losses by evaporation (PASSIOURA; ANGUS et al., 2005). The soil compaction due to the higher animal concentration per unit area may also have contributed to the lower soybean growth and yield under the pasture height of $15 \mathrm{~cm}$, as previously observed in other studies (DEBIASI; FRANCHINI, 2012; FLORES et al., 2007). In contrast, the lower grazing pressure hindered the plant establishment and growth because of the large SDM on the soil at the soybean sowing, as already reported by other authors (CONSTANTIN et al., 2009; DEBIASI; FRANCHINI, 2012; MONQUERO et al., 2010; OLIVEIRA JR. et al., 2006; SANTOS et al., 2007). Therefore, the SDM on the soil resulting from a grazing pressure of $35 \mathrm{~cm}$ provided the best environment for soybean establishment, growth and yield.

The soybean plant density, plant height and first pod insertion height increased linearly with the increase in the interval between desiccation and soybean sowing (Figure 2). Although the SDM on the soil surface was not influenced by pasture desiccation time (Table 3), the increase in the time between desiccation and soybean sowing probably enhanced the straw cutting by the planter disks, improving the seed germination and seedlings emergence due to lower straw incorporation into the soil as well as reduced amounts of exposed seeds. Nascente and Crusciol (2012) also observed increased plant density with increased interval between desiccation and sowing. As a consequence of the higher soybean plant density, plant and first pod insertion heights also increased. Moreover, a longer interval between the pasture desiccation and soybean sowing may have enabled a greater nutrient release through straw

Table 3 - Straw dry mass on the soil surface at the soybean sowing and soybean yields at different intervals between Urocholoa ruziziensis desiccation and soybean sowing (averaged over three pasture heights and three soybean varieties). Londrina, PR, Brazil, 2012/13 growing season

\begin{tabular}{lcc}
\hline $\begin{array}{l}\text { Interval between } \\
\text { desiccation and } \\
\text { sowing (days) }\end{array}$ & $\begin{array}{c}\text { Mass of straw } \\
\left(\mathrm{Mg} \mathrm{ha}^{-1}\right)\end{array}$ & Grain yield $\left(\mathrm{kg} \mathrm{ha}^{-1}\right)$ \\
\hline 35 & $7.28 \mathrm{a}^{1}$ & $3970 \mathrm{a}$ \\
28 & $7.24 \mathrm{a}$ & $3825 \mathrm{a}$ \\
20 & $7.18 \mathrm{a}$ & $4187 \mathrm{a}$ \\
8 & $7.11 \mathrm{a}$ & $4104 \mathrm{a}$ \\
$\mathrm{CV}(\%)$ & 17.6 & 12.1 \\
\hline
\end{tabular}

${ }^{1}$ Means followed by the same letters in a column do not differ by the Tukey test at $5 \%$ probability level 
Figure 2 - Plant density, plant height, and first pod insertion height at different intervals between $U$. ruziziensis desiccation and soybean sowing (averaged over three pasture heights and three soybean varieties). Londrina, PR, Brazil, 2012/13 growing season. *Significant at $5 \%$ probability
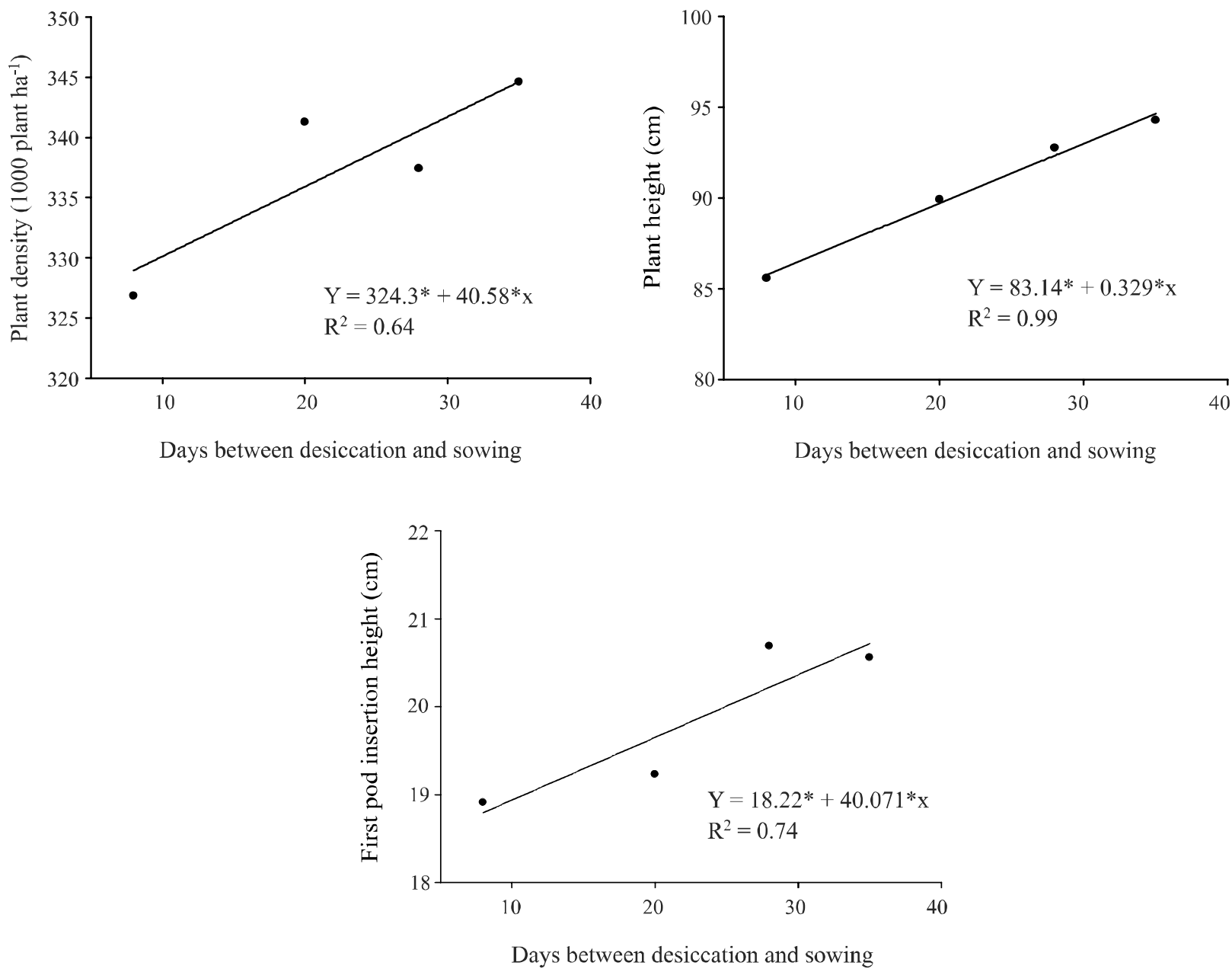

mineralization during soybean vegetative stage, thus resulting in an increased plant growth.

Despite the significant influence on plant density and growth, the desiccation time did not affect the soybean grain yields (Table 3), mainly due to high soybean phenotypic plasticity. Another relevant finding was the absence of significant interaction between grazing pressures and desiccation times on soybean plant density and height, first pod insertion height, and grain yield. The hypothesis that an earlier herbicide application would be necessary under conditions of larger pasture residual dry mass was not confirmed in our study. Nascente and Crusciol (2012) concluded that the desiccation time of $U$. ruziziensis, ranging from 0 to 30 days before sowing soybeans, did not significantly influence soybean growth and yield, whereas reduced soybean yields were reported when
Panicum maximum and $U$. brizantha pastures were desiccated with less than 10 days prior to soybean sowing. According to Debiasi and Franchini (2012), intervals between $U$. brizantha desiccation and soybean sowing shorter than 44 days decreased the soybean yields when the pasture residual dry mass was greater than $9 \mathrm{Mg} \mathrm{ha}^{-1}$. Considering a $U$. ruziziensis dry mass varying from 6 to $10 \mathrm{Mg} \mathrm{ha}^{-1}$, Nepomuceno et al. (2012) concluded that an period of 10 to 20 days between the $U$. ruziziensis desiccation and soybean plant is best suited to maximize the soybean yields, whereas the soybean growth was impaired when the pasture desiccation was done either too early (20 days before the sowing) or too late (at the sowing day).

Among the cultivars evaluated, Vmax RR showed the lowest plant density (Table 4). The lowest plant height was observed for the cultivar NA 5909 
Tabela 4 - Plant density, plant height, first pod insertion height and yields of three soybean cultivars sown after a grazed Urocholoa ruziziensis pasture (averaged over four desiccation times and three pasture heights). Londrina, PR, Brazil, 2012/13 growing season

\begin{tabular}{lcccc}
\hline \multicolumn{1}{c}{ Cultivars } & $\begin{array}{c}\text { Plant density }(1000 \\
\left.\text { plants ha }{ }^{-1}\right)\end{array}$ & Plant height $(\mathrm{cm})$ & $\begin{array}{c}\text { First pod insertion } \\
\text { height }(\mathrm{cm})\end{array}$ & Grain yield $\left(\mathrm{kg} \mathrm{ha}^{-1}\right)$ \\
\hline NA 5909 RR & $352 \mathrm{a}^{1}$ & $79.2 \mathrm{~b}$ & $19.1 \mathrm{~b}$ & $4135 \mathrm{a}$ \\
BMX Potência RR & $343 \mathrm{a}$ & $95.5 \mathrm{a}$ & $17.7 \mathrm{c}$ & $4130 \mathrm{a}$ \\
Vmax RR & $317 \mathrm{~b}$ & $97.1 \mathrm{a}$ & $22.7 \mathrm{a}$ & $3800 \mathrm{~b}$ \\
CV $(\%)$ & 8.3 & 8.3 & 13.2 & 9.3 \\
\hline
\end{tabular}

${ }^{1}$ Means followed by the same letters in a column do not differ by the Tukey test at $5 \%$ probability level

$R R$, whereas the lowest first insertion height occurred in the cultivar BMX Potência RR. The higher grain yields were obtained with the cultivars NA 5909 RR and BMX Potência RR. In general, the soybean yields were high, revealing the great potential for soybean production in CLS under NT.

\section{CONCLUSIONS}

1. Longer intervals between Urochloa ruziziensis desiccation and soybean sowing increased the soybean plant density and height, without significantly affecting grain yields, regardless of the soybean cultivar and straw dry mass on the soil resulting from grazing pressures;

2. In a crop-livestock farming system, the highest soybean yield was obtained when the $U$. ruziziensis pasture were managed at a height of $35 \mathrm{~cm}$, corresponding to a straw dry mass on the soil of approximately $7 \mathrm{Mg} \mathrm{ha}^{-1}$;

3. The performance of the three soybean cultivars evaluated was not influenced by the interaction between straw dry mass and desiccation time of Urochloa ruziziensis.

\section{ACKNOWLEDGMENTS}

Manuscript approved for publication by the Editorial Board of Embrapa Soja (35/2013). A. A. Balbinot Junior receives a fellowship of technological development and innovative extension from CNPq.

\section{REFERENCES}

ARATANI, R.G. et al. Desempenho de semeadoras-adubadoras de soja em Latossolo Vermelho muito argiloso com palha intacta de milho. Revista Brasileira de Engenharia Agrícola e Ambiental, v. 10, n. 2, p. 517-522, 2006
BALBINOT JUNIOR, A. A. Manejo das plantas daninhas pela alelopatia. Agropecuária Catarinense, v. 17, n.1, p. 61-64, 2004.

BALBINOT JUNIOR, A.A. et al. Integração lavourapecuária: intensificação de uso de áreas agrícolas. Ciência Rural, v. 39, n. 6, p. 1925-1933, 2009.

BALBINOT JUNIOR, A. A. et al. Intervalos de tempo entre a dessecação de pastagem de azevém e a semeadura de feijão, soja e milho. Scientia Agraria, v. 12, n. 1, p. 89-96, 2011.

BARTH NETO, A. et al. Italian ryegrass establishment by self-seeding in integrated crop-livestock systems: effects of grazing management and crop rotation strategies. European Journal of Agronomy, v. 53, n. 1, p. 67-73, 2014.

CONSTANTIN J. et al. Sistemas de manejo de plantas daninhas no desenvolvimento e na rendimento da soja. Bragantia, v. 68, p. 125-135, 2009.

DEBIASI. H.; FRANCHINI, J.C. Atributos físicos do solo e rendimento da soja em sistema de integração lavourapecuária com braquiária e soja. Ciência Rural, v. 42, n. 7, p.1180-1186, 2012.

FERREIRA, D.F. SISVAR: um programa para análises e ensino de estatística. Revista Symposium, v. 6, n. 1, p. 36- 41, 2008.

FLECK, N.G. et al. Interferência de picão-preto e guanxuma com soja: efeitos da densidade de plantas e época relativa de emergência. Ciência Rural, v. 34, n. 1, p. 41-48, 2004.

FLORES, J. P.C., et al., Atributos físicos do solo e rendimento de soja em Sistema plantio direto em integração lavoura-pecuária com diferentes pressões de pastejo. Revista Brasileira de Ciência do Solo, v. 31, n. 4, p.771-780, 2007.

FOLEY, J.A. et al. Global consequences of land use. Science, v. 309, p. 570-574, 2005.

HEIFFIG, L.S. et al. Fechamento e índice de área foliar da cultura da soja em diferentes arranjos espaciais. Bragantia, v. 65 , n. 2, p. 285-295, 2006.

MATALLO, M.B. et al. Microwave-assisted solvent extraction and analysis of shikimic acid from plant tissues. Planta Daninha, v. 47, n. 2, p. 187-192, 2012. 
MONQUERO, P.A. et al. Intervalo de dessecação de espécies de cobertura do solo antecedendo a semeadura da soja. Planta Daninha, v. 28, p. 561-573, 2010.

NAIR, P.K.R. et al. Carbon sequestration in agroforestry systems. Advances in Agronomy, v. 108, p. 237-307, 2010.

NASCENTE, A.S.; CRUSCIOL, C.A.C. Cover crops and herbicide timing management on soybean yield under no-tillage system. Pesquisa Agropecuária Brasileira, v. 47, n. 2, p.187192, 2012

NEPOMUCENO, M.P. et al. Períodos de dessecação de Urochloa ruziziensis e seu reflexo na rendimento da soja RR. Planta Daninha, v. 30, n. 3, p. 557-565, 2012.

OLIVEIRA JUNIOR, R.S. et al. Interação entre sistemas de manejo e de controle de plantas daninhas em pós-emergência afetando o desenvolvimento e a rendimento da soja. Planta Daninha, v. 24, n. 4, p. 721-732, 2006.

PACHECO, L.P. et al. Produção de fitomassa e acúmulo e liberação de nutrientes por plantas de cobertura na safrinha. Pesquisa Agropecuária Brasileira, v. 46, n. 1, p. 17-25, 2011.
PASSIOURA, J.B.; ANGUS, J.F. Improving productivity of crops in water-limited environments. Advances in Agronomy, v. 106, n. 1, p. 37-75, 2010.

RICCE, W.S.; ALVES, S.J.; PRETE, C.E.C. Época de dessecação de pastagem de inverno e produtividade de grãos de soja. Pesquisa Agropecuária Brasileira, v. 46, n. 10, p. 1220-1225, 2011.

SANTOS, J.B. et al. Época de dessecação anterior à semeadura sobre o desenvolvimento da soja resistente ao glyphosate. Planta Daninha, v. 25, n. 4, p. 860-875, 2007.

SOUZA, L.S. et al. Efeito alelopático de capim-braquiária (Brachiaria decumbens) sobre o crescimento inicial de sete espécies de plantas cultivadas. Planta Daninha, v. 24, n. 4, p. 657-658, 2006

TREZZI, M.M.; VIDAL, R.A. Potencial de utilização de cobertura vegetal de sorgo e milheto na supressão de plantas daninhas em condição de campo II - Efeitos da cobertura morta. Planta Daninha, v. 22, n. 1, p. 1-10, 2004.

YAMADA, T. et al. Efeitos do glifosato nas plantas: implicações fisiológicas e agronômicas. Informações Agronômicas, n. 119, p. $1-32,2007$ 